\title{
Veils, Crucifixes, and Public Sphere: What Kind of Secularism? Rethinking Neutrality in a Post-Secular Europe*
}

\begin{abstract}
The Lautsi case attracted widespread attention in Europe and beyond. Though the issue in contention was a Christian symbol, the European Court of Human Rights (ECHR) judgements showed changes in assessment both about religion (in contrast with former cases regarding Muslim veils) and secularism (which did not have the same meaning for everyone). In light of those rulings, this paper reflects on the concepts of neutrality and secularism, and their normative implications for European citizens in terms of sense of belonging, solidarity, and cohesion. An open and plural public sphere, in which intercultural exchange can flourish, is crucial if Europe is serious about the integration of its immigrants, many of whom possess a Muslim background. A "post-secular" Europe may have to reconsider long-held stereotypes about religion, and nuance its self-understanding as "secular," in a way that religious citizens can identify with Europe too. The discussion will draw on the ideas of Taylor, Casanova, Habermas, Weiler and Beck to illustrate some of the political, ethical and theoretical complexities of the Lautsi case in Italy, specifically issues to do with neutrality, secularism and the role of religion in the public sphere.
\end{abstract}

Keywords: European citizens, intercultural dialogue, neutrality, public sphere, religion, secularism, secularity, solidarity, worldviews

The down of the XXI century has seen the presence of religion in the public sphere grow globally. The "return of the gods" has been marked in the West by rather unpleasant memories, among which those of 9/11 result emblematic. ${ }^{\text {The }}$

\footnotetext{
*A later version of this article appeared in the Journal of Intercultural Studies, Vol. 35, Issue 4, June 2014.

${ }^{1}$ The sense in which the "return of the gods" phrase is used here, looks to the fact that religion and the supernatural ("the gods"), contrary to what the classic (i.e. Modern, Max Weber style) secularisation theory predicted, did not disappear with progress. If anything, the gods "mutated" and today they re-appear not only in varied new forms, but even in the old traditional ways. The reason why the Christian crucifix and the Islamic veil (and minarets) have caused so much controversy and grasped so much attention in the public sphere is not that they are just symbols, but religious ones. That "secular Europe" would be discussing issues like these so passionately reveals such "return of the gods". It does not necessarily mean that Europeans will or should "surrender" to them, or make a reverse of a thousand years and re-instate Islamic caliphates or Christian kingdoms. It just means that the issue of religion is there today as was before: to be accurate, the gods never left, but public memory has become (again) aware of their presence. Viewed from this perspective, the lively discussion about the permissibility of religious symbols in public schools is just a concrete chapter in the overall phenomenon of the returning gods. For deeper analyses on this idea, see, among many others: Davie G. (2006) Religion in Europe in the 21 Century: The Factors to Take into Account. European Journal of Sociology 47: 271-296, Byrnes TA and Katzenstein PJ. (2006) Religion in an expanding Europe, Cambridge, UK ; New York: Cambridge University Press, Casanova J. (2008) Public Religions Revisited. In: Vries Hd (ed) Religion: Beyond the Concept. Paperback ed. New York: Fordham University Press, 101119, Weber M and Parsons T. (2003) The Protestant Ethic and the Spirit of Capitalism: Dover
} 


\section{Public Education, Veils, and Crucifixes: What Kind of Secularism?}

apocalyptic predictions of the Mayan calendar for 2012 are another sign that provokes thoughts, discussions, movies and trips to the pyramids in southern Mexico. Europe, even those parts of it where religion had greatly diminished its public presence, has not been an exception and is having its dose of religion as well, even if in a less picturesque way.

Indeed, today Europe (and in particular the 27 member-state polity, the European Union or EU) is confronted-again-with the issue of religion in the public sphere. ${ }^{2}$ Yet apart from isolated incidents of violence, ${ }^{3}$ Europe is increasingly at odds with religion for a different reason. A large proportion of immigrants, residents, and citizens have a Muslim background. In other words, for many European citizens Islam is an important part of who they are, and how they find motivation, meaning and purpose for their lives.

The "Muslim problem" (i.e. the difficulty that some Europeans have understanding and accepting residents and citizens of Islamic background or culture) at times motivates illiberal or undemocratic attitudes which betray longheld prejudices about Muslims in particular and religion in general. Such attitudes challenge presuppositions and promises of liberal democracies in two ways.4 First, by feeding anxiety about how much public tolerance can there be to the inclusion of citizens notwithstanding their religiosity. Secondly, by stiring fear that the presence of religion in the public sphere will threaten the foundations of the modern constitutional state-grounded upon neutrality and secularity for very specific reasons.

In the next lines this paper takes from a case before the ECHR on religious symbols to illustrate a few complexities of the "problem of religion" in Europe, to evaluate some assumptions about religion and neutrality in the public sphere, and to draw some normative implications for harmonious coexistence, solidarity and political identity of Europe in the post-secular age. 5

Publications, (2005) Secular Europe and Religious America: Implications for Transatlantic Relations. (accessed 11 Nov 2010), Habermas J. (2010) An Awareness of What is Missing Faith and Reason in a Post-Secular Age, Cambridge: Polity Press, Habermas J. (2006) Religion in the Public Sphere. European Journal of Philosophy 14: 1-25, Habermas J. (2008a) Notes on a Post-secular Society. signandsight.com - let's talk European. Beck U and Livingstone R. (2010) A God of One's Own: Religion's Capacity for Peace and Potential for Violence: John Wiley \& Sons.

${ }^{2}$ Croatia is set to officially become the $28^{\text {th }}$ member state in July 2013.

3 Theo van Gogh's assassination by a Muslim extremist on the 2d of November 2004 is an example. Though extremism does not seem an exclusive of Islam, as Anders Breivik's shotting of nearly 100 young members of the Labour Party on the 22d of July 2011 at the Utøya Island demonstrated.

4 For a discussion on the link between liberal democracy and culture, see: Jiménez Lobeira PC. (2011a) Liberal Democracy: Culture-free? Habermas, Ratzinger \& Europe. Australian \& New Zealand Journal of European Studies

Vol.2(2)/3(1): 44-57.

5 I am indebted to members of the Project on European Identity at the Centre of Excellence Foundations of European Law and Polity (University of Helsinki), and participants at the seminar "Lautsi v Italy, Whose Law? Which Religion?" held at the University of Helsinki on September 2011, to Dr John Besemeres, and two anonymous reviewers for very helpful comments on earlier versions of this paper. 


\section{Veils, Crucifixes and Public Education}

On the $18^{\text {th }}$ of March 2011, the ECHR ("the Court") gave its final word over a controversy that had lasted nearly a decade. The Lautsi and others $v$ Italy (or "Lautsi") case had attracted increasing attention first in Italy and eventually in Europe and beyond. The issue in contention was if crucifixes should be taken down from classroom walls in Italian public schools. ${ }^{6}$

The applicant, Ms Soile Lautsi, a Fin married to an Italian (Mr Massimo Albertin), found it unacceptable that her two children (Dataico and Sami) should see every day a crucifix hanging from the classroom walls in the public school they attended.7 She argued that the presence of crucifixes on the walls infringed her parental right to educate her children according to her philosophical convictions; her right to freedom of thought, conscience, and religion; and her right to manifest her own beliefs (alluding to Article 2, Protocol 1, and Article 9 of the European Convention on Human Rights, or "the Convention"). 8 Together with her husband, Ms Lautsi belongs to the Italian Union of Atheists, ${ }^{9}$ Agnostics and Rationalists (organisation member of the European Humanist Federation, and of the International Humanist Ethical Union). ${ }^{10}$

\footnotetext{
${ }^{6}$ Cf ECHR GCot. (2011) Case of Lautsi and Others v Italy. In: Rights ECoH (ed) Application no. 30814/o6. Strasbourg: ECHR, 51.

7 In this article, arguments from both the applicant and the defendant are, for reasons of space, greatly synthesised. Many details are omitted in a case which started in 2002 and went through several levels of justice administration in Italy (Veneto Administrative Court, Italy's

Constitutional Court, Italian Supreme Administrative Court) before it got to the ECHR. And at the ECHR there are many nuances that arise from comparing the first and second cases. For the complete information refer to the case itself (footnote number 2). Here reference is made only to specific aspects that are essential for the analysis of neutrality in the European public sphere.

8 ECHR GCot. (2011) Case of Lautsi and Others v Italy. In: Rights ECoH (ed) Application no. 30814/o6. Strasbourg: ECHR, 51. This international treaty is called: "Convention for the Protection of Human Rights and Fundamental Freedom," though it is commonly refer to (even by the Council of Europe) with the abbreviated name. (2010a) European Convention on Human Rights. European Court of Human Rights. (accessed 4 Feb 2012).

9 For very comprehensive treatments of the phenomenon of secularism, which includes the reemergence of both religions and atheism, see, among many other studies: Taylor C. (2007) $A$ secular age: Belknap Press of Harvard University Press, Taylor C. (2009) The Polysemy of the Secular. Social Research 76: 1143-1166, De de Botton A. (2012) Religion for Atheists: A nonbeliever's guide to the uses of religion: Penguin Books Limited, Byrnes TA and Katzenstein PJ. (2006) Religion in an expanding Europe, Cambridge, UK ; New York: Cambridge University Press, Casanova J. (2004) Religion, European Secular Identities, and European Integration. Eurozine. (accessed 17 Aug 2010), Casanova J. (2009) The Secular and Secularisms. Social Research 76: 1049-1066, Scott D and Hirschkind C. (2006) Powers of the secular modern : Talal Asad and his interlocutors, Stanford, Calif.: Stanford University Press, Davie G. (2006) Religion in Europe in the 21 Century: The Factors to Take into Account. European Journal of Sociology 47: 271-296, Dawkins R. (2006) The God Delusion: Houghton Mifflin Company, Hahn S and Wiker B. (2008) Answering the New Atheism: Dismantling Dawkins' Case Against God: Emmaus Road Pub.

10 ECHR GCot. (2011) Case of Lautsi and Others v Italy. In: Rights ECoH (ed) Application no. 30814/o6. Strasbourg: ECHR, 51. Their websites are, respectively: http://www.uaar.it/, http://humanistfederation.eu/, and http://www.iheu.org/,
} 


\section{Public Education, Veils, and Crucifixes: What Kind of Secularism?}

The defendant, the Government of Italy, argued that the crucifix was a passive symbol; part of the Italian national identity; a summary of Italian and Western values such as non-violence, equal dignity of all human beings, justice and sharing, forgiveness to one's enemies, separation of politics and religion, and freedom of choice. The Government argued as well that there was no consensus on how to interpret the principle of secularism among the member countries of the Council of Europe; that the majority in Italy wanted crucifixes in the classrooms; and that "neutrality"-an "inclusive" concept-was being confused with "secularism"-an "exclusive" concept.11

The ECHR's first ruling (2009) went in favour of Ms Lautsi. ${ }^{12}$ In keeping the crucifixes on public school classroom walls, the State was, even if perhaps indirectly, imposing religious beliefs on young minds. Negative freedom of religion-for instance atheism-asserted the Court's judgement, deserved especial protection. The display of religious symbols could not be justified even by the desire of the majority of parents (as was the case in the public school Ms Lauti's children attended) to have them there. The State should take religion out of this public space, in order to educate the children in "pluralism" and "critical thinking", and to preserve a "democratic society". ${ }^{13}$

In past cases related to religious symbols the Court had ruled in favour of banning women who wore Islamic headscarves from attending university (Sahin v Turkey), ${ }^{14}$ teaching in public school classrooms (Dahlab v Switzerland), ${ }_{15}^{15}$ or even entering their schools (Dogru; and Kevanci; v France).16 Therefore, the 2009 decision of the Court on Lautsi was consistent with the application of the "principle of secularism" (separation of religion and politics) understood in a particular way: religion should be out of the public sphere, and remain private. But was that what the principle ought to mean in terms of neutrality?

A group of 20 states (mostly from Central and Eastern Europe) sided with Italy in her appeal to the ECHR's Grand Chamber (its ultimate instance) to review the ruling. ${ }^{17}$ Eight of those countries participated collectively in the oral procedure as third party intervening states, asking Joseph HH Weiler, Professor of Law at New York University, to present arguments on their behalf. ${ }^{18}$ He accepted. During a 15 minute intervention before the 17 Judges forming the Grand Chamber, Weiler-

${ }^{11}$ Ibid.

${ }^{12}$ ECHR SS. (2009) Case of Lautsi v Italy. Ibid., 15.

13 Ibid.

${ }^{14}$ ECHR GCot. (2005) Case of Leyla Şahin v Turkey. In: Rights ECoH (ed). 165 numbers.

15 ECHR. (2001) Dahlab v Switzerland. In: Rights ECoH (ed). Strasbourg.

${ }^{16}$ ECHR FS. (2008b) Case of Dogru v France. In: ECHR (ed). ECHR FS. (2008a) Affaire

Kervanci c. France. In: ECHR (ed).

${ }_{17}$ Albania, Armenia, Austria, Bulgaria, Croacia, Cyprus, Greece, Hungary, Lithuania, (FYR of) Macedonia, Malta, Moldavia, Monaco, Polonia, Romania, Russia, San Marino, Serbia, Slovakia and Ukraine. Cf ECHR GCot. (2011) Case of Lautsi and Others v Italy. In: Rights ECoH (ed) Application no. 30814/o6. Strasbourg: ECHR, 51.

${ }_{18}$ Armenia, Bulgaria, Cyprus, Greece, Lithuania, Malta, Russia, and San Marino. See: Weiler JHH. (2010b) Oral Submission by Professor Joseph Weiler before the Grand Chamber of the European Court of Human Rights. ilsussidiario.net. Online ed. 
a practicing Jew, wearing a yarmulke-dug deep into the meaning of neutrality and secularism for democracies in Europe.

Weiler pointed out that many public symbols have a religious origin. In Europe, the Cross was the most visible example, appearing on flags, crests, buildings, and other places. The Cross was neither a purely national nor a solely religious symbol. It was both. One logical consequence of the 2009 ECHR ruling would be that photos of the Queen should be removed from public spaces in the UK, because she is both Head of the State and of the Church of England. Using a similar rationale (mentioned by Weiler in an editorial), British children should be preserved from listening (even less, learning) the national Anthem (God Save the Queen). ${ }^{19}$ For Weiler, mandating a "naked wall", especially when a religious symbol had been there for centuries, was not "neutral", but rather an endorsement of a worldview-secularism-over religion. ${ }^{20}$ Indeed, it was "legally disingenuous to adopt a political position which splits our society, and to claim that somehow it is neutral." ${ }_{21}$

Under Weiler's perspective plurality implies a public sphere in which different worldviews (e.g. secularist, Christian, Jewish, Muslim, and others) coexist respecting each other. Banning the presence of one or several of them from the public sphere was questionable in principle, and divisive in practice. In fact, "the position adopted by the [Second] Chamber [in 2009]" was "not an expression of the pluralism manifest by the Convention system, but an expression of the values of the laïque [ie secularist] State." ${ }_{22}$ For Weiler, a pluralist education might require the school precinct to reflect the pluralism in society-some rooms with naked walls, some with crucifixes, some with Stars of David, some with Stars and Crescents. ${ }^{23}$ This task, though, was for every country-not for the ECHR-to decide (e.g. France has a model of "laicism"; Denmark and Finland have state religions). ${ }^{24}$

The Court's final word came in March 2011. By an overwhelming majority the Grand Chamber reversed the Second Chamber's ruling. ${ }^{25}$ The decision whether

\footnotetext{
19 Cf Weiler JH. (2010a) Lautsi: Crucifix in the Classroom Redux. European Journal of International Law 21.

${ }^{20}$ (2010b) Joseph Weiler argues high-profile classroom crucifix case before European Court of Human Rights. NYU School of Law News. (accessed 4 Feb 2012).

${ }^{21}$ Weiler JHH. (2010b) Oral Submission by Professor Joseph Weiler before the Grand Chamber of the European Court of Human Rights. ilsussidiario.net. Online ed.

22 Ibid.

${ }^{23}$ Weiler JH. (2010a) Lautsi: Crucifix in the Classroom Redux. European Journal of International Law 21.

24 Weiler JHH. (2010b) Oral Submission by Professor Joseph Weiler before the Grand Chamber of the European Court of Human Rights. ilsussidiario.net. Online ed.

25 The Court's Grand Chamber held, by 15 votes to 2, that there had been no violation of Article 2 of Protocol 1 ("...the State shall respect the right of parents to ensure such education and teaching in conformity with their own religious and philosophical convictions"), and that no separate issues arose under Article 9 of the Convention (freedom of thought, conscience and religion); and it held unanimously that there was no cause to examine the complaint under Article 14 of the Convention (prohibition of discrimination on any ground). Cf (2010a) European Convention on Human Rights. European Court of Human Rights. (accessed 4 Feb 2012).
} 
crucifixes should be present in State-school classrooms fell under the margin of appreciation of the Italian State. ${ }^{26}$ The fact that there was no European consensus regarding the presence of religious symbols in State schools spoke in favour of that approach. The crucifix, though clearly a religious symbol, was also a passive one, and did not, in the case of Italian public schools, imply obligation for any student to receive religious instruction or participate in related rites or activities. ${ }^{27}$

Ms Lautsi, the Court commented, had possessed the right to inculcate in her children her own worldview without interference. Children were allowed to attend the school wearing symbols associated with their worldviews, such as Islamic headscarves..$^{28}$ The Court found "nothing to suggest that the authorities were intolerant of pupils who believed in other religions, were non-believers or held non-religious philosophical convictions." 29

The Court's Grand Chamber considered that the State should ensure, impartially, the exercise of various religions, faiths and beliefs, in order to promote public order and tolerance. ${ }^{30}$ Their role was to "help maintain public order,...harmony, and tolerance in a democratic society," concerning "both relations between believers and non-believers and relations between the adherents of various religions, faiths and beliefs". ${ }^{11}$ The Convention did not "prevent States from imparting, through teaching or education, information or knowledge of a directly or indirectly religious or philosophical kind.” The Convention did require States to take care that "information or knowledge included in the curriculum" was conveyed "in an objective, critical and pluralistic manner," and "in a calm atmosphere free of any proselytism." ${ }_{32}$

A final important point of the Grand Chamber's ruling was its acknowledgement that "supporters of secularism" were able "to lay claim to views" with "the 'level of cogency, seriousness, cohesion and importance' required for them to be considered 'convictions"'.33 Secularism must be regarded as a philosophical conviction worthy of respect in a democratic society.34

The Lautsi case is emblematic of a wider discussion. In both rulings, the Court's judges cited former cases where the point in contention had been the possible presence (or not) of religious symbols or contents, in the public sphere. The underlying normative assumption is that the public sphere should not be

\footnotetext{
${ }^{26}$ ECHR GCot. (2011) Case of Lautsi and Others v Italy. In: Rights ECoH (ed) Application no. 30814/o6. Strasbourg: ECHR, 51.

${ }_{27}$ Thus it did not denote indoctrination. Ibid. See a precedent regarding religious education in Norway: ECHR GC. (2007) Case of Folgerø and Others v Norway. In: Rights ECoH (ed). Strasbourg. ${ }^{28}$ ECHR GCot. (2011) Case of Lautsi and Others v Italy. In: Rights ECoH (ed) Application no. 30814/o6. Strasbourg: ECHR, 51.

29 Ibid.

30 "Critical thinking" was not mentioned as incompatible with any worldview, religious or not. Compare with the Second Section's judgement: ECHR SS. (2009) Case of Lautsi v Italy. Ibid., 15 .

${ }^{31}$ ECHR GCot. (2011) Case of Lautsi and Others v Italy. Ibid.: ECHR, 51.

32 Ibid.

33 Within the meaning of Article 9 of the Convention and Article 2 of Protocol 1: ibid.

34 Ibid.
} 
religious; or in positive terms, that it should be "secular". A secular public sphere guarantees equality for all citizens, sustained by a neutral state.

However, the concepts of "neutrality" and "secularism" were invoked by the two contending parties, and used by the Court following a different interpretation in each of the two rulings). The terms have appeared in the abundant literature around the case before and after the final decision, used by those who agree with it and those who do not. The main misunderstanding seems to lie in what the concepts mean, and in particular the specific way in which secularism and neutrality are related. This question is analysed next.

\section{Secularity and Secularism}

During the ECHR cases dealing with the public presence of religion, neutrality is always seen as a good, as a desirable characteristic of those exercising power and authority, and of the medium-the public sphere-in which formal and informal deliberation of citizens takes place.

In order to understand both the concept and the importance of neutrality in the modern state today, a very synthetic contextualisation could be in place. Habermas explains how a religious mentality founded on the literal interpretation of sacred scriptures encountered some times among Christian, Islamic, Jewish or Hindu groups, "clashes with fundamental convictions of modernity". 35 The neutrality of the state implies an even-handed treatment of different worldviews within the polity in order to ensure "equal freedom of religion for all" ${ }^{6}$ Conflicts between worldviews "dominated large parts of modern European history", and

...today they are being repeated not only in relations between the western and Islamic worlds but also in those between militant groups of religious and secularized citizens within liberal societies. We can view these conflicts either as power struggles between state authority and religious movements or as conflicts between secular and religious convictions. 37

Analytically, neutrality translates into a public political atmosphere that allows citizens and groups of citizens holding different worldviews, to live in harmony, and agree in fundamental public questions, with the rest of the political community. Normatively, neutrality denotes the safeguard of the modern values of "equality," "freedom," and at least a pre-condition for solidarity or "fraternity"-if we may borrow these terms from what Taylor calls the "French Revolutionary trinity". ${ }^{8}$ Furthermore, the very legitimacy of constitutional democracies lies in the support of reasons "which can be accepted in a pluralist

\footnotetext{
35 Habermas J. (2010) An Awareness of What is Missing - Faith and Reason in a Post-Secular Age, Cambridge: Polity Press.

${ }^{36}$ Ibid.

37 Ibid.

${ }^{88}$ Taylor C. (2009) The Polysemy of the Secular. Social Research 76: 1143-1166.
} 
society by religious citizens, by citizens of different religions, and by secular citizens alike". 39

Now Habermas's account shows an evolution in the concept of neutrality. Originally, neutrality (whose most evident manifestation came to be the secular state) would have arisen as a practical solution to conflicts between groups professing different religious views. In the case of, for instance, XVII century Europe that translated into wars and mutual persecutions between Christian denominations or "confessions".40 To this situation Locke's thoughts on toleration attempted to propose a solution. 41 A version of this concept of "confessional neutrality" is used by the Court in the first (2009) ruling. Religion is viewed as troublesome and a source of conflict. It does not have a place in the public sphere. The state "has a duty to uphold confessional neutrality in public education....which must seek to inculcate in pupils the habit of critical thought". ${ }^{42}$

Yet Habermas does not confine his reflections to religious citizens only, but to those who hold non-religious worldviews as well, since everybody with a worldview, not only religious people, has the potential to become confronting and intolerant of the views of others. 43 He sees us as living in a "post-secular" age, one in which religion and secularism continue to exist, and must engage in dialogue not only about, but also with each other.44 The thought of neutrality therefore is closely connected to that of secularism. It is the latter that requires a more careful exploration in order to bring light on the former and on the whole discussion of this paper.

As Taylor has shown, "secular" is a polysemic term. ${ }^{45}$ Historically it developed in Latin Christendom (from its previous use with the Romans). Secular (from saeculum) means "the century", a profane ("earthly") time as opposed to a higher (eternal) time. Hence "secular" could mean "temporal" in contrast with "eternal" or "spiritual". In a different nuance, secular clergy was that operating "in the century" as opposed to that under monastic rules (or "regular" clergy). As a gradual process (which cannot be explained here due to lack of space) of "secularisation" took place in the former Western (or "Latin") Christendom, while at the same time many people went on believing in the transcendent, "secular"

\footnotetext{
39 Habermas J. (2010) An Awareness of What is Missing - Faith and Reason in a Post-Secular Age, Cambridge: Polity Press.

40 Judaism was the official religion of no king or state and therefore Jewish people in Europe were, at the best tolerated, awfully often persecuted, and shamefully for Europe and for humanity exterminated towards the middle of the XX century-and not only in Germany. ${ }^{4141}$ Locke advocates toleration towards all denominations and religions (with the only exception of Atheists and Catholics), and separation of political affairs from doctrine and faith. Locke J. (2010) A Letter concerning Toleration and Other Writings In: Goldie M (ed). Indianapolis: Liberty Fund.

42 ECHR SS. (2009) Case of Lautsi v Italy. In: Rights ECoH (ed) Application no. 30814/o6. Strasbourg, 15. I leave for the moment the reference to "critical thought", but the implication about religious citizens is obvious.

43 See above.

44 Habermas J. (2010) An Awareness of What is Missing - Faith and Reason in a Post-Secular Age, Cambridge: Polity Press.

45 Taylor C. (2009) The Polysemy of the Secular. Social Research 76: 1143-1166.
} 
came to mean the opposite concern, with "things of this world" or immanence. 46 The history of the term in the West is "complex and ambiguous," with "secular" starting as part of a dyad to distinguish two dimensions of existence (temporal or immanent, spiritual or transcendent). However, around the XVIII century

...it mutates into a term in another dyad, where "secular" refers to what pertains to a self-sufficient immanent sphere, and its contrasting term (often identified as "religious") relates to the transcendent realm. This can then undergo a further mutation...into a dyad in which one term refers to the real (the secular), and the other to what is merely invented (the religious); or where "secular" refers to the institutions we really require to live in "this world," and "religious"...to optional extras that often disturb the course of this-worldly life. 47

Today, "it is generally agreed that modern democracies have to be 'secular", continues Taylor. But even in the Western context "the term is not limpid". It involves "some kind of separation of church and state", yet "secularism requires more than this." 48 Before we follow Taylor in his explanation (continued below) of the public good towards which secularism should be intended, an analytical distinction could be beneficial. Several authors, including Taylor, Casanova to a lesser extent, and others, tend to use "secular", "secularity" and "secularism" almost interchangeably.49 After all that is the way it is used in common language, and in law cases related above. However, "secularism" should be specified if its relation with neutrality is to become clearer.

According to Casanova, secularism may mean either a statecraft postulate, or an ideology. In its first denotation secularism entails "some principle of separation between religious and political authority, either for the sake of neutrality of the state vis-à-vis each and all religions, or for the sake of protecting the freedom of conscience of each individual, or for the sake of facilitating the equal access of all citizens", religious or not, "to democratic participation." ${ }^{\circ}$ Every form of statecraft secularism entails two principles: 1) separation (of church and state) or "no establishment" of any religion, and 2) free exercise of conscience (to believe or not to believe). The first principle, pluralism of worldviews, should serve the second, freedom and equality for all citizens. The latter is a necessary condition for democracy, an end in itself. But it is possible to have the former without democracy, especially when "secularism" ceases to be a formal device of statecraft and acquires substantive form..$^{51}$

If that happens, says Casanova, secularism turns "ideological," i.e. it becomes a normative standing, especially when it "arrogates for itself the mantle of

${ }^{46}$ Cf ibid.

47Ibid.

48 Ibid.

49 For instance Cécile Laborde in her very interesting (even for those of us who do not share her point of view) defence of the banning of the scarves in France: Laborde C. (2005) Secular

Philosophy and Muslim Headscarves in Schools*. Journal of Political Philosophy 13: 305-329.

${ }^{50}$ Casanova J. (2009) The Secular and Secularisms. Social Research 76: 1049-1066.

51 "Soviet-type regimes, Kemalist Turkey, or post-Revolutionary Mexico being obvious examples.”Ibid. 
rationality and universality, while claiming that 'religion' is essentially nonrational, particularistic, and intolerant (or illiberal)" and therefore "a threat to democratic politics once it enters the public sphere." These ideas "can hardly be grounded empirically in the collective historical experience of European societies in the twentieth century or in the actual experience of most contemporary Europeans", yet they constitute a construct

...that has the function of positively differentiating modern secular Europeans from "the religious other," either from premodern religious Europeans or from contemporary non-European religious people, particularly from Muslims. ${ }^{2}$

Perhaps what Casanova denominates "secularism as statecraft" could be alternatively designated as "secularity;" and what for him is "secularism as ideology" could be simply called "secularism". "Secularity" denotes a feature that characterises a certain atmosphere, or a political arrangement, or a style of government. "Secularism," like many other "-isms" implies a movement or promotion of ideology, doctrines or belief systems. 53

Indeed, many aspects of "the secular" are highly desirable today not only for "secularists" but also for agnostics and most believers in Western societies. Habermas has made a similar distinction after describing a "Kulturkampf" between "radical multiculturalists" and "militant secularists" in the context of post-secular societies. According to him, a "secular or unbelieving person...relates agnostically to religious validity claims" under an "indifferent stance". In contrast,

...secularists tend to adopt a polemical stance towards religious doctrines that maintain a public influence despite the fact that their claims cannot be scientifically justified. Today, secularism is often based on "hard" naturalism, i.e., one based on scientistic assumptions. 54

With this distinction in mind let us now return to Taylor's discussion (started above) about the public good (or the purpose) of what we are calling secularity (started above). For him secularity "involves...a complex requirement"-which are in reality normative goals. The first requirement is "liberty," so that "...no-one must be forced in the domain of religion, or basic belief...including...the freedom not to believe..." The second, "equality... between people" of different worldviews, in a way that "no...religious or areligious...Weltanschauung can enjoy privileged status, let alone be adopted as the official view of the state." And third, "fraternity," meaning that "all spiritual families must be...included in the ongoing process of determining what the society is about (its political identity), and how it is going to realize these goals (the exact regime of rights and privileges),"

$5^{2}$ Ibid.

53 Think of Marxism, Confucianism, or Republicanism, for instance.

54 Habermas J. (2008a) Notes on a Post-secular Society. signandsight.com - let's talk European. 
maintaining, as much as possible "relations of harmony and comity between the supporters of different...Weltanschauungen".55

Whether the normative goals of secularity find their best depiction in Taylor's account is open to debate. But note how his discussion focuses on what we are calling secularity; whereas what we have called secularism can be identified within each one of the goals as a worldview alongside others (religions included). This is a distinction that the Grand Chamber of the ECHR, unlike the Second Chamber, acknowledges right from the beginning of its final decision (as related above). Let us now consider how these distinctions might play out in the European public sphere. For that we will use a description of the cultural atmosphere in which Western societies live today.

As we have seen before, unlike a situation similar to, say, that of the 1500 , when it was "virtually impossible not to believe in God" today we live in "a secular age," one in which "faith, even for the staunchest believer, is one human possibility among others." ${ }^{6}$ The "buffered identity of the disciplined individual, moves in a constructed social space, where instrumental rationality is a key value, and time is pervasively secular." Taylor calls this atmosphere the "immanent frame," which constitutes a "natural" order, as opposed to a "supernatural" one, "an 'immanent' world, over and against a possible 'transcendent' one." ${ }_{7}$ This immanent frame in which we live can "slough off the transcendent. But it doesn't necessarily do so..." Some people living in it as open to something beyond, some do not. "It is something which permits closure, without demanding it." 58

Now what with Habermas we have called "secularity" here corresponds to Casanova's "statecraft secularism" and to Taylor's "immanent frame". It is the de facto cultural atmosphere in which we live. And that is not problematic as long as such atmosphere remains "open"-receptive of, or at least tolerant towardscultural positions which look beyond, to the possibility of transcendence. An open immanent frame means that the cultural medium of secularity is substantively, normatively "neutral"-neither privileging a cultural position or worldview above others, nor excluding any of them.

Hence an open immanent frame bears an inclusive public sphere. Yet, when the immanent frame turns from secular to secularist it becomes "closed": one among the many worldviews held by citizens in the public sphere becomes the exclusive (or at least a strongly privileged) view. Citizens who do not share that worldview must adapt their outlooks in order to fit with the official Weltanschauung, or else risk being left out-or at the margins-of public participation. A closed immanent frame is neither neutral nor inclusive.

\footnotetext{
55 Taylor C. (2009) The Polysemy of the Secular. Social Research 76: 1143-1166.

${ }_{56}^{6}$ Taylor C. (2007) A secular age: Belknap Press of Harvard University Press. Due to lack of space I will not expound on the why and how our age is secular. Taylor's work is deeply insightful and comprehensive in that respect.

57 Ibid.

${ }^{8} \mathrm{Ibid}$. For further explanation on how the immanent frame can be open or closed, see pp. 546ss.
} 


\section{Neutrality in Post-secular Societies}

A "post-secular" society is one that has been "secular" first. Habermas cites as examples affluent countries in Europe, as well as Canada, Australia and New Zealand. These regions "have witnessed a spreading awareness that their citizens are living in a secularized society".59 These would be typical examples of societies living in Taylor's "secular age". So what is "post-secular" about them? Only the fact that the relevance of religion has not, as it had been hypothesised in the past, waned (the necessary link between secularisation and modernisation is now increasingly challenged).60

Among the phenomena that create "the impression of a worldwide 'resurgence of religion" Habermas mentions: "the missionary expansion" (of Hinduism, Buddhism, Judaism, Christianity, and Islam in different regions of the world), "a fundamentalist radicalisation" (of certain groups within Christianity and Islam mainly) and "the political instrumentalisation of the potential for violence innate in many of the world religions" (of Hindu nationalism, partially Pakistani Islam, the mullah regime in Iran, and "the mobilisation of the religious right in the United States" around the invasion of Iraq in 2003).61

Today "public consciousness in Europe can be described as 'post-secular" due to a "change in consciousness" where "the certainty that cultural and social modernisation can advance only at the cost of public influence and personal relevance of religion" has been shaken. Religion is not only "gaining influence worldwide" but also within national public spheres. More concretely, "the Muslims next door...give the secular citizens a keener consciousness of the phenomenon of the public presence of religion." Indeed the "issue of tolerant coexistence...is made harder by the difficult problem of how to integrate immigrant cultures socially." 62

The preceding descriptive account gives place to normative questions, such as

...whether a secularist devaluation of religion, if it were one day to be shared by the vast majority of secular citizens, is at all compatible with the post-secular balance between shared citizenship and cultural difference...63

And in my view this is the key point that defines how neutrality in the public sphere should be understood. Though the right mix for a balanced, harmonised society is certainly a big challenge, the concept of neutrality cannot disregard equality between citizens of the same polity, on the one hand, or recognition of their cultural differences on the other, inasmuch as culture and religion are often important components of citizens' identities. Equality, after all, implies mutual respect:

\footnotetext{
59 Habermas J. (2008b) Notes on Post-Secular Society. New Perspectives Quarterly 25: 17-29.

6o Ibid.

${ }^{61}$ Ibid.

62 Ibid.

63 Ibid.
} 
Do the selfsame normative expectations that rule an inclusive civil society not prohibit a secularist devaluation of religion just as they prohibit, for example, the religious rejection of equal rights for men and women? 64

However, respect is only the beginning. The basis for inclusion, sense of belonging, and eventually solidarity to be created in the political community requires also "a complementary learning process" as necessary on the part of religious as on that of the "secular side unless we confuse the neutrality of a secular state...with the purging of the political public sphere of all religious contributions." ${ }_{55}$

\section{Individual Cosmopolitanism, Religion and Peaceful Co-existence}

It would seem that largely the consensus in today's liberal democracies is for secularity, as has been defined above: an arrangement that permits plurality of Weltanschauungen-both secularist and religious. That has been to position suggested by this paper so far: a public frame that is secular and open to (tolerant of) the possibility of transcendence. In order to clarify a little more such ideas, it could be helpful to contrast them with a recent proposal on this field.

Ulrich Beck's call to all religions to become a force for good in today global arena is interesting and insightful. He definitely realises that religion in the XXI century is very far from disappearing and is a reality that must be taken into account in his native Germany, in "secular Europe" and elsewhere. His "individual cosmopolitanism" seeks to solve the difficulty between competing (absolute) truths and the possibility of peace, and calls for a pragmatic arrangement from religions to cooperate towards global justice (alleviation of poverty, mitigation of climate change, attention to immigrants and refugees, and so forth) and avoid the danger the world faces today of self-annihilation. Hardly anyone could disagree with the goals he proposes.

His analysis, however, reveals a few assumptions which would be difficult to endorse, at least in the way in which they are expressed in his book. Beck's proposal would not be, in other words, the kind of secularity best for problems such as the one illustrated in Lautsi.

The first questionable assumption regards his conception of religion vis-à-vis reason: often it would seem that for him they are mutually exclusive; 66 implicitly, the prerogative of rationality stays for him with secular thinking. Yet the secular can turn secularist (fundamentalist) and therefore irrational. He does not seem to contemplate this possibility, and relates the world wars of the XX century to

64 Ibid.

65 Ibid.

${ }^{66}$ For instance: "The threat that is ultimately conjured up by the death of a secular hope is the rebirth of religious warriors and religious wars..." Beck U and Livingstone R. (2010) A God of One's Own: Religion's Capacity for Peace and Potential for Violence: John Wiley \& Sons. He also associates religion (only) and danger or even violence (ibid.). 


\section{Public Education, Veils, and Crucifixes: What Kind of Secularism?}

"the linkage of nation, religion and violence," ${ }^{67}$ overlooking that those conflicts, while certainly containing evident doses of violence and nationalism, did not have a religious cause (and were perpetrated, as Casanova points out, by secular totalitarian regimes which rather persecuted religion). ${ }^{68}$

As has been submitted above, fanaticism is not a monopoly of religion, but a tendency in which any human individual or group can fall if not careful, usually motivated by things that are good but become absolutes. Then anyone outside the correct doctrine or worldview becomes a pariah who must be persecuted or eliminated. There are great rational, thinking human beings with the apparently more contrasting worldviews, and they can still tolerate and argue with each other. The exchange of ideas between secular thinker Jürgen Habermas and religious thinker, Joseph Ratzinger in 2005 is but one example.69 There are as well abundant examples of people-religious or not-with intolerant attitudes, irrational views, and violent behaviours.

Whether, for instance, there is a "God" or not, be it in the strong sense given by the monotheistic religions; or in the sense given to the term in polytheistic or pantheistic religions; or even in the much weaker, quasi-postmodern, immanentist and therefore secular conception that Beck himself seems to have about the "God" (or god?) "of one's own;"7o or whether simply there is no God, as Dawkins would sustain; ;1 is certainly a matter for contention. But the fact that the matter can be discussed in a rational, "civilised" way bespeaks of a human rationality which people on both sides of the discussion are capable.

The second problematic assumption has to do with Beck's conceptions of "truth" in connection with "peace". If each person has a different opinion about, say, God (or any other issue, for that matter), can the discussion be solved by affirming that "everybody is right," or everybody has their truth and a "God" of their own? Is that not another way of saying, either that in the end nobody has the (real, objective) truth about the issue? This is not a pattern of thought we apply to topics that are important to our age. We would not use it to speak, for instance, about climate change, evolution or human rights. People may take different positions and disagree even strongly with others about them, but the issue is not solved by saying that "everybody is right".72

\footnotetext{
${ }^{67}$ Beck U and Grande E. (2010) Varieties of second modernity: the cosmopolitan turn in social and political theory and research. The British Journal of Sociology 61: 409-443.

68 Casanova J. (2009) The Secular and Secularisms. Social Research 76: 1049-1066.

${ }^{69}$ See an analysis on their dialogue in: Jiménez Lobeira PC. (2011b) Liberal Democracy: Culture Free? The Habermas-Ratzinger Debate and its Implications for Europe. Australian \& New Zealand Journal of European Studies Volume 2, No 2 / Volume 3, No 1.: 44-57.

${ }^{70}$ Beck U and Livingstone R. (2010) A God of One's Own: Religion's Capacity for Peace and Potential for Violence: John Wiley \& Sons.

${ }^{71}$ See: Dawkins R. (2006) The God Delusion: Houghton Mifflin Company. And the interesting and opposed view in: Hahn S and Wiker B. (2008) Answering the New Atheism: Dismantling Dawkins' Case Against God: Emmaus Road Pub.

${ }^{72}$ In fact, Beck himself holds, as every person does, certain principles to be true. For instance, he rightly defends the truth about human rights. See: Beck U and Livingstone R. (2010) A God of One's Own: Religion's Capacity for Peace and Potential for Violence: John Wiley \& Sons.
} 
And this point is important not only in inter-religious dialogue, but also more broadly in dialogue between contending comprehensive worldviews, or systems of belief, whether religious or secular.73 Dismissing the discussion about the "God" issue by saying that everybody/nobody is right (or has the truth) about it, is not necessarily a path towards peace.74 Intuitively, and following a line that Taylor, Ratzinger and Habermas have undertaken each in their own way,75 an interlocutor with a different system of belief to mine would probably more-and not less-disposed towards peace if she knows that I consider seriously what she says as possibly true; if she thus feels recognised; and if she perceives that rather than concealing my own views, I can honestly give reasons for what I believe, even if that may be in contrast or opposition with her view.

Opening up to the possibility that an issue of vital importance (and heated controversy) for large groups of people may actually have a true answer; or that some answers may be closer to the truth about it than others; does not detract, however, from what seems to be Beck's main purpose in his proposal. Peace could be worked out through the pragmatic acceptance between people of different worldviews, that even if they do not agree on a subject, and even if there is a chance that some of them may be more or less right about it, they still should agree on carrying on the discussion in civilised and rational ways. Fundamentalists should not be able to impose their views on others by force. 76 But of course this should hold for fundamentalists or any kind-religious or secular.

The third dubious assumption in Beck's analysis regards the place his own, normative position has in relation to worldviews, religious or secular. It would seem by his account that his individual cosmopolitanism is above worldviews, therefore out of danger of being substantive (and therefore partial). Thus his position would be able to mediate and comprehend the religious worldviews and establish harmony and peace between them. ${ }^{77}$ But is not his position a variation of a secular system of belief, therefore a creed as well that is to be placed not above

\footnotetext{
73 E.g. the New Atheism of Richard Dawkins, Christopher Hitchens, Daniel Dennett and Sam Harris, its "Four Horsemen".

$74 \mathrm{He}$ seems to be ready to sacrifice any substantive truth in the benefit of peace. Yet he still holds as true the "rules, treatises, procedures" such as the human rights and the rule of law. Beck U and Livingstone R. (2010) A God of One's Own: Religion's Capacity for Peace and Potential for Violence: John Wiley \& Sons. But are concepts like human rights, the rule of law, democracy pure formal conventions? Have they not arisen in specific circumstances, and do they not possess a substantive content in agreement with a certain world view? There is reason why, the concept of human rights for instance has been interpreted and given a substance very differently in the Western world, in the Arab world and in China.

75 See for instance: Taylor C, Gutmann A, Appiah KA, et al. (2011) Multiculturalism: (Expanded paperback edition): Princeton University Press. Benedict. (2004) Truth and tolerance : Christian belief and world religions, San Francisco: Ignatius Press. Habermas J. (2006) Religion in the Public Sphere. European Journal of Philosophy 14: 1-25.

${ }^{76}$ Beck U and Livingstone R. (2010) A God of One's Own: Religion's Capacity for Peace and Potential for Violence: John Wiley \& Sons.

77 Ibid.
} 
but alongside the rest of communities and systems of faith?78 Habermas, whom Beck would appear to wish outdoing, 79 is much clearer and more aware that his own position is also a worldview. 80

Beck's individual cosmopolitanism possesses, according to him, the capacity to bring religions from the borders of fundamentalism, irrationality, and violence, to a situation in which they renounce to uphold the absolute truth they claimed to have, and rather cooperate with the rest in a pragmatic way to attain the goal of global peace. ${ }^{81}$

Beck's position should therefore be open to religions as they are and try to make them work together from a formal, value-free standpoint. But this is not possible for three reasons. First, he restricts his scope to those systems of belief that are "problematic" in his view: religions. Not a word about secular systems of belief. Second, his own stance is secular and substantive (not neutral). And third, he advances a normative perspective on religion (the God of one's own, which is as much an empirical but partial reality in some societies, as it is a suggestion on what religion should be in the XXI century). ${ }^{82}$

Now that makes Beck's position at least unstable. If he wants religions to come under individual cosmopolitanism to become cooperative and peaceful, Beck should clearly recognise, as Habermas does, that his position is substantive and secular (located within Taylor's immanent frame). But that would create in other systems of belief, a sense of unfairness (why the system of belief of individual cosmopolitanism has to rule over other systems of belief, say over Islam or over New Atheism?). Further, if his position regards the "God" talk ("of one's own in this case) as pure figure of speech, then people for whom religion is a serious matter, and a reality, would not have much reason to pay him attention. ${ }^{83}$ Or, if

\footnotetext{
${ }^{78}$ Ibid. Beck recurs to Durkheim to base his cosmopolitanism: “...the only possible candidate is precisely this religion of humanity whose rational expression is the individualistic morality." "The idea on which individualisation is based, namely, the belief that the individual is sacred, states that man has become a god for man." "And in the interior of the religion of the godlike individual, altars are erected to a God of one's own." Accordingly, Becks asserts that "Amnesty International may be said to represent a modern church dedicated to a 'god of its own"'. 79 See: ibid.

80 See, for instance: Habermas J. (2010) An Awareness of What is Missing - Faith and Reason in a Post-Secular Age, Cambridge: Polity Press.

${ }^{81}$ Beck U and Livingstone R. (2010) A God of One's Own: Religion's Capacity for Peace and Potential for Violence: John Wiley \& Sons.

82 He expresses a new dogma that religions ought to follow, the "principle of religious truth," according to which "in religious matters, there is no truth apart from the personal truth that one has acquired through one's own efforts" (ibid.) But how well would this principle impress the many religions-Judaism, Islam, and others-that claim that truth ("religious" or not) has been revealed by powers beyond any human being? Could Beck's position arise positive answers from religious people, with statements like those? Can religious people feel addressed by a discussion that repeatedly speaks of "churches" a foreign concept to non-Christian religions? See, as an example: ibid.

$8_{3}$ And if his intention is to appeal to religious people and to institutionalised religions with oficial doctrines, Beck does his cause Little favour by assuming several times throughout the book that religious people tend "to denigrate followers of other faiths as unbelievers or heretics and to question their human dignity." Ibid. But that assertion would be at least inaccurate for a vast majority of religious people. For starters, "unbelievers" would not necessarily be equivalent
} 
he actually is holding a genuine religious view (a real belief in God of some kind), he good then would lose attention from atheists and other secular systems of belief for whom immanence is all there is in this field (of "God" or "gods").

Beck's stands a very interesting proposal. It is a positive invitation to construct a better atmosphere and to amend past mistakes, by bringing people and groups from all creeds to the table. ${ }^{84}$ It seeks to go beyond pure controversy to find workable solutions, and that is certainly well located intellectually to address the new challenges the world faces in the XXI century.

Yet as it is hoped has been shown in the precedent sections, concrete problems like the ones revealed in Lautsi can be better addressed using a nuanced approach such as the combination of Habermas's, Casanova's, Taylor's and Weiler's perspectives.

\section{Conclusion}

The need for an inclusive public sphere and for a concept of "neutral neutrality," one in which secularity and secularism are distinguished, is felt not only in Europe's "affluent societies," but also in other regions of the world. As mentioned above, among those considered more secularised (and therefore susceptible of undergoing a "post-secular" experience are Canada, New Zealand and Australia.

Lautsi $v$ Italy showcases a subject that will become increasingly important in Europe. Apart from the legal intricacies (for instance the discussion about the "margin of appreciation") on which I do not have space or competence to comment, the final decision could signal a positive trend for neutrality in the European public sphere. Secularity seems to have earned a place in contemporary democracies as the best arrangement of political power and social order so far. The model has travelled and been applied successfully in other regions of the world (including Australia). Europe should be proud of this achievement, found after centuries of strife and division.

Furthermore, secularity should be the formal and procedural structure adopted in face of the challenge of integrating new European residents and citizens, many of whom possess diverse cultural backgrounds. Secularity promises an arena which is neutral, and at any rate plural and inclusive of all members of the political community: those who believe, those who do not, those who have not made up their minds, and those who are not interested in the discussion. Worldviews, Weltanschauungen, "philosophies of life," religions, normative positions, belief systems, "comprehensive views of the good," as long as they are held by European citizens should all be both, respected and included in the public sphere on equal ground.

to "heretics" for many of them, nor would the fact that others had a different system of belief be a reason to question their human dignity. That is certainly the case for Christians today, as it is for New Atheists.

84 Ibid. 
Secularism is a respectable worldview or normative position; and so it should be as much for those who profess it, as for those who do not share it. Islam should receive equal public dignity and respectability. A religion held by millions of people worldwide, it has produced extraordinary cultural developments since the VIII century. Its thinkers were genuine intellectual counterparts to the greatest European minds of the Middle Ages. It is a religion that brings purpose and meaning to millions of European citizens today. There is no reason why Muslims should be marginalised from the public sphere.

Unfortunately (or perhaps, fortunately) violence, stubbornness, closedmindedness, intolerance, and rashness of judgement, cannot be pinned down to one worldview only. It seems to be a human thing into which people of any worldview (religious or not) if not careful, can fall. The pretence that some worldviews are neutral by default is mistaken and damaging. If a strong, cohesive and renewed political community is to be constructed in Europe, the public sphere has to be plural and inclusive of all worldviews-eminently when those worldviews are important for significant sectors of the population. The only way to build a liberal democracy is by being truly liberal and democratic.

If citizens (as is overwhelmingly the case of Muslims in Europe) are willing to abide by the laws of the polity, respect the secular structures, participate in political life, and engage in deliberation in the public sphere, there is no reason why they should be stigmatised, marginalised or diminished in any way just because they are religious, or engage in public religious practices or rites, or choose in their freedom to wear headscarves. The same respect should be shown for Europeans of other religions and worldviews. Only a public sphere which is in principle open, plural, inclusive, substantively and normatively neutral, will make the task of building mutual recognition, intercultural exchange, equality, solidarity, and eventually a common political identity, possible.

\section{REFERENCES}

(2005) Secular Europe and Religious America: Implications for Transatlantic Relations. (accessed 11 Nov 2010).

(2010a) European Convention on Human Rights. European Court of Human Rights. (accessed 4 Feb 2012).

(2010b) Joseph Weiler argues high-profile classroom crucifix case before European Court of Human Rights. NYU School of Law News. (accessed 4 Feb 2012).

Beck U and Grande E. (2010) Varieties of second modernity: the cosmopolitan turn in social and political theory and research. The British Journal of Sociology 61: 409-443.

Beck U and Livingstone R. (2010) A God of One's Own: Religion's Capacity for Peace and Potential for Violence: John Wiley \& Sons.

Benedict. (2004) Truth and tolerance : Christian belief and world religions, San Francisco: Ignatius Press. 
Byrnes TA and Katzenstein PJ. (2006) Religion in an expanding Europe, Cambridge, UK ; New York: Cambridge University Press.

Casanova J. (2004) Religion, European Secular Identities, and European Integration. Eurozine. (accessed 17 Aug 2010).

Casanova J. (2008) Public Religions Revisited. In: Vries Hd (ed) Religion: Beyond the Concept. Paperback ed. New York: Fordham University Press, 101-119.

Casanova J. (2009) The Secular and Secularisms. Social Research 76: 1049-1066.

Davie G. (2006) Religion in Europe in the 21 Century: The Factors to Take into Account. European Journal of Sociology 47: 271-296.

Dawkins R. (2006) The God Delusion: Houghton Mifflin Company.

De de Botton A. (2012) Religion for Atheists: A non-believer's guide to the uses of religion: Penguin Books Limited.

ECHR. (2001) Dahlab v Switzerland. In: Rights ECoH (ed). Strasbourg.

ECHR FS. (2008a) Affaire Kervanci c. France. In: ECHR (ed).

ECHR FS. (2008b) Case of Dogru v France. In: ECHR (ed).

ECHR GC. (2007) Case of Folgerø and Others v Norway. In: Rights ECoH (ed). Strasbourg.

ECHR GCot. (2005) Case of Leyla Şahin v Turkey. In: Rights ECoH (ed). 165 numbers.

ECHR GCot. (2011) Case of Lautsi and Others v Italy. In: Rights ECoH (ed) Application no. 30814/o6. Strasbourg: ECHR, 51.

ECHR SS. (2009) Case of Lautsi v Italy. In: Rights ECoH (ed) Application no. 30814/o6. Strasbourg, 15.

Habermas J. (2006) Religion in the Public Sphere. European Journal of Philosophy 14: 1-25.

Habermas J. (2008a) Notes on a Post-secular Society. signandsight.com - let's talk European.

Habermas J. (2008b) Notes on Post-Secular Society. New Perspectives Quarterly 25: 17-29.

Habermas J. (2010) An Awareness of What is Missing - Faith and Reason in a Post-Secular Age, Cambridge: Polity Press.

Hahn S and Wiker B. (2008) Answering the New Atheism: Dismantling Dawkins' Case Against God: Emmaus Road Pub.

Jiménez Lobeira PC. (2011a) Liberal Democracy: Culture-free? Habermas, Ratzinger \& Europe. Australian \& New Zealand Journal of European Studies

Vol.2(2)/3(1): 44-57.

Jiménez Lobeira PC. (2011b) Liberal Democracy: Culture Free? The HabermasRatzinger Debate and its Implications for Europe. Australian \& New Zealand Journal of European Studies Volume 2, No 2 / Volume 3, No 1.: 44-57.

Laborde C. (2005) Secular Philosophy and Muslim Headscarves in Schools*. Journal of Political Philosophy 13: 305-329. 
20 Public Education, Veils, and Crucifixes: What Kind of Secularism?

Locke J. (2010) A Letter concerning Toleration and Other Writings In: Goldie M (ed). Indianapolis: Liberty Fund.

Scott D and Hirschkind C. (2006) Powers of the secular modern : Talal Asad and his interlocutors, Stanford, Calif.: Stanford University Press.

Taylor C. (2007) A secular age: Belknap Press of Harvard University Press.

Taylor C. (2009) The Polysemy of the Secular. Social Research 76: 1143-1166.

Taylor C, Gutmann A, Appiah KA, et al. (2011) Multiculturalism: (Expanded paperback edition): Princeton University Press.

Weber M and Parsons T. (2003) The Protestant Ethic and the Spirit of Capitalism: Dover Publications.

Weiler JH. (2010a) Lautsi: Crucifix in the Classroom Redux. European Journal of International Law 21.

Weiler JHH. (2010b) Oral Submission by Professor Joseph Weiler before the Grand Chamber of the European Court of Human Rights. ilsussidiario.net. Online ed. 